\title{
GOVERNANCE IN PRACTICES: DELIMITATION AND CONTESTATION IN ADULT EDUCATION AND TRAINING POLICY IN PORTUGAL
}

\author{
Fátima Antunes \\ University of Minho, Portugal \\ fantunes@ie.uminho.pt
}

\section{ABSTRACT}

This paper explores the governance of education, focusing on the terrain of practices. The analysis articulates the centrality of public authorities, such as the state-by discussing the mandate and the governance arrangement-with the approach of the policy cycle, by taking into account the "context of practices." In the context of the development of public adult education and training policy in Portugal in the first decade of the twenty-first century, the paper discusses the movement towards an instrumental extension of the governance circle through agency distribution by public and private, civic, cultural, charity and commercial entities. Based on the testimonies of the heads of these entities, the text discusses their appropriations and reactions concerning the meaning of the policy at hand and its relationship with the state, along with the terms for contracting educational services, as well as the mandate and scope of educational activities. On the one hand, empirical data suggest that concerns regarding governability support the subordination of the agents contracted and nurture the state's evasion from its commitments to the population's rights and demands; on the other hand, several testimonies evoke contestation and interstitial practices that try to enlarge the scope of the community's embeddedness in socio-educational and pedagogical interventions.

Keywords: adult education and training policy; agency; education policy analysis; governance; Portugal; state reform
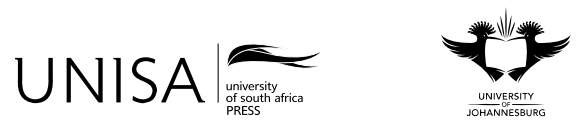

Education as Change www.educationaschange.co.za 


\section{THE STATE'S REFORM AND GOVERNANCE: TENSIONS AND AMBIVALENCES ${ }^{1}$}

For many decades, at a distinct pace and at different latitudes, the state's activity has intensified in the creation of new forms of educational provision (as well as other goods and services which embody social rights). These developments have been discussed as a shift from government to governance (see e.g. Jessop 1995); in my view, this formula underlines changes in the different forms of socio-political coordination, by which the state (or political authorities, e.g. the EU) is reconstructed and assumes new forms and priorities (central for doing what or on whose behalf?). In the 1990s in Portugal, governance was visibly altered in the areas of vocational education, child education and, later, adult education. In the first and last cases, this was accompanied by forms of intervention by the state, which were clearly temporary, together with programmes that were made possible by funding from the European Union. It was also in these sectors that one observed the state's successful appeal for social mobilisation in the area of education, directed both at entities involved in the development of policies, as well as those targeted by these policies. Progressively, an educational universe of shifting frontiers was fabricated with "hybridized organizational forms, innovative arrangements of governance" (Newman and Clarke 2012, 353), "the involvement of a multiplicity of new providers of different kinds, and the redistribution of power and responsibility" (Junemann and Ball 2013, 423).

Governance has progressively condensed some of the recent political and theoretical debates; it has simultaneously become a naturalised theme, and yet the issues it raises and the knowledge of the social practices it involves are still controversial and weakly consolidated.

Cast into the midst of the crises of capitalism and democracy, and following contradictory criticisms and proposals about legitimacy and governability, the programme of governance-understood as a socio-political regulation matrix of hegemonic orientation-is thematised from the latter (Santos 2005). This is the direction of the tendencies and proposals of change, which revolve around privatisation, commercialisation and liberalisation, and constitute a dominant feature of the years between 1980 and 1990. On the other hand, the grievances voiced by the people, with demands for inclusion and social justice, have also marked the political agenda of governance. Extending the governance circle, in terms of interests, benefits, participation and projects, constitutes an open horizon of practices and political struggles in order to strengthen the link between this innovation and social emancipation. In turn, the

1 This study was supported by national funding from the FCT_-Fundação para a Ciência e a Tecnologia (Foundation for Science and Technology) (Project PEst-OE/CED/UI1661/2014). I am very grateful to the anonymous reviewers of this paper, who made very stimulating and challenging commentaries and recommendations. 
agendas centred on autonomy and self-regulation also identify the questions raised by the welfare state's social contract regarding the crisis of governability (Santos 2005).

However, as will be seen further on, these aspirations for autonomy and selfregulation are also shared by social actors and experimentations mobilised in favour of recognition and popular participation; so, their political sense depends first on the world views, concepts and practices through which they are formulated and proceed. Ambivalence can then emerge in the terrain of struggles and socio-political practices, its significance and consequences depending on the correlation of forces and the conjunctures in which they take place (see Santos 2005).

In this debate, the theoretical proposal that considers a managerial state allows one to scrutinise the significance of some connections between the political options and privileged institutional arrangements. This analytical angle suggests a debate on the impact of managerialism, as an ideology and a political project, in the relationships "between state and citizen, between public and private, between the providers and recipients of social welfare, and between 'management' and 'politics"' (Clarke and Newman 1997, ix).

This conceptual framework allows us to clarify the abandonment of the normative and procedural principles, typical of the formal commitments, centrally negotiated in the context of the welfare state and the orientation towards "specific outcomes," "explicit and prescriptive," whose "formally contractualised" regulation is based on the participants' "performance requirements" (Seddon, Billet, and Clemans 2005, 570). The adoption of this order of commandments inspired by the so-called new public management (NPM) has frequently been accompanied by placing under contingency the social and human rights of either producers or beneficiaries of public services.

The following discussion attempts to understand some of the developments of the institutional arrangement of governance during experimentation with the device for the Recognition, Validation and Certification of Competences (Reconhecimento, Validação $e$ Certificação de Competências, RVCC), set within the framework of adult education and training (AET) in Portugal, observing the practices that materialise the institutional arrangement of governance through the testimonies provided by heads of the New Opportunities Centres (NOC-Centros Novas Oportunidades).

\section{ADULT EDUCATION AND TRAINING IN PORTUGAL: A NEGLECTED LANDSCAPE}

The institutional construction of the welfare state in Portugal in the 1990s and 2000s was characterised by the tension between welfare state models and, consequently, between guidelines that are more conducive to market dependence or to social investment (Hespanha, Ferreira, and Pacheco 2014, 197, 192). The trajectory of social policies in Portugal oscillated, at this time, between a perspective of strong state intervention in the provision of services and responses and a conception of "untying the State from the 
promotion of these services ... with preferential intervention of the State in a subsidiary role" (Hespanha, Ferreira, and Pacheco 2014, 192-3).

In the field of education, among other changes, begins the country's involvement in Europeanisation dynamics, which assume some specificities, given the particular conditions of Portuguese educational realities. Some of these specificities were translated by the simultaneous crisis and consolidation of the mass school (and the welfare state), but also by the development at the same time of so-called (and controversial) generations of rights: civil and political, economic and social, and cultural (Santos 1997). From the end of the eighties of the twentieth century the public debate becomes stronger about the redefinition of the role of the state as the main protagonist in the regulation, financing, ownership and provision of education, responsible for the creation of a universal public education system as prescribed by the Constitution of the Portuguese Republic of 1976. The so-called (second) decade of transition (Afonso 1998) thus established a new role for the state in education in Portugal, which, in fact, initiated a path that was to be consolidated in the following decades and that involved certain options in the organisation of social welfare services connoted with the reform of the managerial state (Clarke and Newman 1997).

From 1989 until today we find a range of public policies that underpin this new role of the state, driven and framed by the funding from the European Union. This new role allows the extension of educational responses; however, by withdrawing provisions it often avoids committing to permanent public policies and structures, which are replaced by temporary programmes and interim bodies fostered by the same funding.

Adult education and training in Portugal is a terrain of political conflict and the absence of a global and integrated public policy and system of adult education and training is a long-lasting structural feature (Melo, Lima, and Almeida 2002). It has been argued that "(i) structural conditions related with socio-historical pathways are responsible for the main parameters of Portuguese adult education policy; (ii) ambivalence and tensions are a result of policy development, generated within the interplay between European, national and local dimensions, among others" (Antunes and Guimarães 2014). Even during the last 40 years of democracy, the discontinuity of policies, goals, and educational and political rationales has been the main condition producing a hybridity of orientations and the fragmentation of the landscape (Melo, Lima, and Almeida 2002). The weakness of civil society, from the point of view of autoorganisation, is another structural condition that brings ambiguity to the processes of policy in action (see for instance, Hespanha et al. 2000; Santos 1993). This has remained so even if, from 1997 to 2011, unprecedented priority, visibility and investment were allocated to an adult education and training public offer. This is due to the fact that even this development occurred within the framework of temporary programmes, anchored on provisional organisms (the New Opportunities Centres-NOCs). The Portuguese State has never assumed a commitment to the education of adult populations through the creation of a permanent specific public organism and structure, with its own funding from the state budget. 
From the late 1990s, an adult education and training policy has been underway in Portugal, aiming to promote economic competitiveness and social cohesion, as stated by the Lisbon Strategy and the European Employment Strategy. This policy has been worked on by grassroots socio-educational activists, progressive pedagogues and even some political decision makers or members of educational administration aiming to enlarge public education, and to provide answers and pathways in order to substantiate the fundamental human right to education of the Portuguese adult population.

The Recognition, Validation and Certification of Competences device was launched in 1999 and was publically financed by European funds and by the state's budget. It was developed by bodies (designated as Centres for the Recognition, Validation and Certification of Competences, the CRVCC, and later the New Opportunities Centres) promoted by various entities, public and private, profit-making and non-profit. These ranged from local development associations to training companies, including schools or training centres belonging to the Employment and Vocational Training Office (Instituto de Emprego e Formação Profissional-IEFP), which is responsible for the public policy of vocational training. The promoters' involvement in this educational response took place through applications based on the contracting of results, financing and human resources for a limited time period (see Antunes 2011; Barros 2012).

\section{THEORETICAL-METHODOLOGICAL DIMENSIONS OF THE ANALYSIS OF EDUCATION POLICIES}

Various studies defend the heuristic potential of articulating a perspective focused on the strategic centres of power and decision in the analysis of educational policies (the state, the EU) with an approach of the policy cycle (see Bowe, Ball, and Gold 1992; Dale 1989). In this way, it is possible to build trajectory analyses (Ball and Shilling $1994,2)$ of socio-political innovations. The goal is to mobilise an analytical perspective that allows for an understanding of reality as a social relationship, with structure and meaningful action, which is both structured and structuring. This implies understanding the action and frameworks, grasping their political meaning, discussing the omissions, tensions and mediations which have weaved conflicts, as well as the commitments and provisional alliances undertaken by the social actors, interests and powers involved.

Thus, a theoretical-methodological approach to the trajectory analysis of sociopolitical innovations has allowed us to conceive the policy-cycle as an articulation of distinct and specific action frameworks, populated by situated social actors (for example, supranational/European, national, regional/local, institutional, professional). Each one of these scenarios constitutes a source of power and influence, which empowers and delimits the action to be enacted in other contexts in specific ways. Following Ball (2009), we consider that these dimensions also express appropriations by the social actors who receive and translate the policies in question into interpretations, courses of action, and institutional and professional practices. The empirical dimension of the discussion 
here developed is devoted to understanding these appropriations and translation in the terrain of educational action, through the testimonies of the New Opportunities Centres heads interviewed.

In this sense, if public policies and practices are globally structured (Dale 2001), they take place in the contexts of action, mobilising the resources, means, institutional possibilities and social actors available which really exist or are possible to create. This does not mean that one has not already seen the development of extremely aggressive policies in the face of a given reality, even when active or larval opposition from social actors present is expected.

Thus, in another recent study of the Recognition, Validation and Certification of Competences device launched in 1999, we propose to combine the approach which considers the centrality of the state's action and that of public authorities like the EU (explaining the source, mandate and governance of the Adult Education Training public policy, when it was launched), with the analysis of "dimensions," "levels" (or "moments") of the policy-cycle (cf. Bowe, Ball, and Gold 1992; Dale 1989). This research has focused, above all, on the context of influence (which includes the activities and protagonists involved in the construction of the structuring purposes, discourses and concepts of the policy) and the context of the production of texts (political and programmatic) and decisions translated into normative texts (cf. Antunes 2011).

The study discussed here mobilises this theoretical-methodological approach of the trajectory analysis of the Recognition, Validation and Certification of Competences device launched in 1999, focusing on the dimension of practices. The information analysed is based in eight interviews, carried out in 2010 and at the beginning of 2011, with a duration period of more than one hour each. The interviewees were people responsible for New Opportunities Centres (NOC) from different institutions. We sought to cover a wide spectrum of entities involved in the Recognition, Validation and Certification of Competences (RVCC) device and in adult education and training policy. We interviewed heads of NOC promoted by one public secondary school, one public centre of vocational training with participated management, one private vocational school, one industrial association, one municipal town council, and three local development associations. So, five interviewees were responsible for NOCs from private institutions and three from the public state sector. The eight interviews were transcribed, totalling approximately 200 pages of text. The interviews were submitted to content analysis by categorising the statements made and developing a set of procedures for the construction of an analysis grid. ${ }^{2}$ In the next point, we build an interpretation, inspired by the categories of heads' understandings and the relationships between these

2 The main categories constructed and retained from the interviews were: (i) The discourse about the policy (41 references by 6 interviewees); (ii) Agency (12 references by 5 interviewees); (iii) Public-private: entities involved; the market logic (12 references by 5 interviewees); (iv) The adult people ( 6 references by 4 interviewees); (v) Auto-representation of the institution ( 5 references by 3 interviewees). In this paper, a part of the constructed data is discussed. 
categories, and we develop a theoretical discussion based on these empirical data. In doing so, we do not intend to generalise any findings about those testimonies; rather, we argue that these can be seen as some empirical expressions of governance in practices, as translated through subjects' policy interpretations and reported educational action.

\section{GOVERNANCE IN PRACTICE: DELIMITATION AND DIVERGENCE OF EDUCATIONAL ACTION}

The study, which is now presented, analyses the dimensions of the practices that embody, interpret and appropriate the socio-political innovation of the Recognition, Validation and Certification of Competences device, set in the framework of the adult education and training policy. The fact that one is dealing with various institutions of which the interviewees are a public face and voice is expressly considered. To this extent, and further along in the study, we shall discuss issues which can be related to the distinct interpretations and institutional appropriations of some of the vectors of the policy in question.

More specifically, in the confluence of the analytical problem of governance and the theoretical-methodological perspective of trajectory analysis, a research itinerary has been designed to allow for the analysis and discussion of the following research issues: 1) in the context of the adult education and training public policy, how is the RVCC device appropriated by those institutions that developed it during the course of the first decade of the twenty-first century? 1.1) Which interpretations do they construct with regard to: a) the relationship with the state in the context of a temporary programme, and b) the institutional formula (of governance) adopted? 1.2) Which orientations and practices do these institutions develop, with regard to: a) their relationship with the state, and $b$ ) the conditions for contracting services, especially those related to results and funding? The next sections proceed by presenting empirically grounded commentary in order to answer these questions.

In the field of adult education, the articulation of the public administration's empowering action with grassroots sociocultural dynamics constitutes the backbone of democratic-participatory models of public policies of adult education (Lima and Guimarães 2011). In this sense, historically, this is a terrain which has visibly been crossed by demands and practices related to what we thematise today as governance, addressing topics such as participation, autonomy, redistribution, recognition, social justice and transformation (Santos 2005). Using Alberto Melo's words, at the turn of the century, as was the case 30 years ago, politics - as grassroots dynamics aiming to build "Adult Education and Training in Portugal as a societal project," "with everyone's participation"-competes with strategic centralised planning, in the framework of programmes which are more suitable for the instrumental and tutored citizens' organised action (cf. Melo 2007). 
By listening to the heads of the New Opportunities Centres, we wished to apprehend the orientations and the practices that constitute the state's relationships with the involved entities, as well as the meaning of the public policy thus constructed, the scope and the terms of the contracted services, the conditions and the implications of such developments.

The interviewees discussed and highlighted the following topics: (1) the relationship with the state, the strategic manager, especially in the case of institutions whose intervention is often empowered and delimited by their instrumental role in the execution of public policies, as a secondary and/or under tutelage $e^{3}$ civil society; (2) the restrictions which ensue from managerial planning, in the context of public and social policies set in temporary programmes; (3) the prevalence of the terms, defined by the state, for service contracting and the tensions ensuing therefrom; (4) the delimitation of educational action by funding; and (5) the local and (inter)institutional appropriation of the policy, described as competition, collaboration and networks.

In the next sections these issues are discussed in terms of theoretical and conceptual tools, such as the mandate (Dale 1989): What are the focus and the scope of educational action? Are they multidimensional and integrated or fragmented and amputated? Furthermore, we intend to reconstruct these questions within the analytical problem of governance (in the sense proposed by Dale 1997, 2009), also understood as the coordination (of functions) of services and activities of welfare (using the terminology which largely converges with Clarke and Newman 1997): Who participates? Under which conditions? What are the effects/results? (What happens to the right to education and sociocultural democratisation?) What is the state's role, as well as that of the local actors and dynamics? (What are the answers to the problems of social redistribution and recognition, and what is the position of the excluded?)

It is, thus, possible to analyse the institutional arrangement in operation and its implications with regard to changes in the welfare service (and in the social rights involved), as well as in the organisation and role played by the state and other institutions (the market, the third sector). One also seeks to understand how the interviewees interpret and position themselves when confronted with the absence of an adult education and training integrated global public policy and system in Portugal. Furthermore, what are the implications that, in their perspective, emerge from these options? The same topics are explored in an attempt to understand the political meaning both of the promulgated measures and, above all, of their appropriation by actors in the field; on that point attention is paid to the (contradictory) practices being constructed, which include a degree of ambiguity, or even the potential ambivalence, of some of those processes and interpretations. The objective of this analytical dimension is to understand the tensions and contradictions of the dynamic and conflicting articulations that nurture political

3 In order to broaden the discussion concerning institutions of the third sector involved in social and educational policies, as a secondary and/or under tutelage civil society, see Santos (1993) and Hespanha et al. (2000). 
action on the "floor" of social and educational relationships. Additionally, it is intended to formulate interrogations concerning its effects and consequences, namely in terms of complex social justice (see Ball 2009).

\section{The State, the Strategic Manager: Contracting and Contestation- Policy Appropriations and Practices}

\section{Questioning Local Recognition and Participation or Service Organisation}

The relationship with the state's tutelage is presented in line with varying points of view, depending on the nature of the institution in which the New Opportunities Centre is embedded. While the interviewees connected to local development associations raise issues related to political-educational options, those linked to public and private systems of education and training, be they school related or not, tend towards a perspective which is more centred on the terms of service contracts and their implications for the institutional domain and educational scope. Thus, as is highlighted by the citation below of the coordinator of the New Opportunities Centre, Topo, the issues related to community integration and the multidimensional and poli-faceted nature of adult education and training are raised exclusively by heads of adult education and training organisms set in the three local development associations. They focus on three main points involving the governance and mandate issues: the implications of their relationship with the state for projects of territorial development, the autonomy of intervention in the context of the community animation dynamics and the action of the entities dedicated solely to the execution of the public policies developed by temporary programmes. The coordinator (female) of the NOC Topo (local development association) states,

At this moment, it is quite set against us, that is, even if we're making a difference in the territory, but we also feel that, from one moment to the next, we will be completely unable to continue the work, which does not end with a certification. So that we, as a local development association, feel that even more greatly, because what we wanted was to create local clubs to motivate the population, promote active citizenship; in the RVCC we have tried to include issues such as equal opportunities, gender equality, entrepreneurship, training, short training sessions or short reflections in talk shops and many others in local areas where we work in a decentralised manner, but what I feel is "okay, this only makes sense if we can continue to do so, if this is assimilated to the point where people become so autonomous that they are then able to set up their own clubs, venues for reflection, on their own; this cannot be done in two years."

The relationships with the central state appear more generally connected to the terms of service contracts. Here, the role of the strategic manager is significant since it defines the conditions and the results to be achieved. Once again, we find different views of this issue, apparently related to the kind of entities that embed the adult education and training organism. We could say that, in different ways, the heads interviewed are talking about how those pre-defined targets are very far away from the lived realities of their adult education and training contexts. For instance, the interviewees that were 
responsible for New Opportunities Centres located in public or private organisations of the education and training system, school related or not, tend to underline the unrealistic nature of these conditions and of the quantitative targets, as well as the ensuing tensions and contradictions resulting therefrom (a problem of regulation/governance, as a service organisation). The coordinator (male) of the NOC Fenix (public centre of vocational training) explains,

For example, we are a type $\mathrm{C}$ team - here at Fenix - so we should have 2000 enrolments per year; we don't even have 1000 but, if we had 2000, the team we have would be incapable of responding; so we end up not having that problem, because there are no (enrolled) adults. But, therefore, the number of staff in the technical team, according to the targets, is out of kilter.

Another coordinator, (female) of the NOC Rosal (a municipal town council), elaborates,

Obviously, one of the levels which have fallen short of our expectations is the number of enrolments. Enrolments have dropped: in this last year, in 2010, we only reached 60 per cent of our targets in terms of enrolments ... Regarding the rate of implementation, we are close to 40 per cent. This has led us to believe that, in fact, it's not always easy; it's not as easy as people say.

Those heads responsible for the NOC promoted by the local development associations highlight these issues too; but they also emphasise that they constitute a "blind policy" in relation to the territories and an amputation of social and educational dynamics (a problem of mandate and of social redistribution/recognition or the political meaning of governance). The coordinator (female) of the NOC Topo (local development association) states,

I consider that the State carried out a blind policy, didn't they? That's what is of interest to the State, the targets and talk about quality, but they forget that the institutions work in a determined context and that context is specific. In our case, this attachment to local dynamics, we have always persisted and, until now, we also have not had great problems with that. Consequently, this is done because we are stubborn and they only let us proceed because we meet the targets; because when we don't meet targets, there will be an immediate cut.

The director (male) of the NOC Vila da Vitória (local development association) further asserts,

naturally, we can have differentiated policies for the same country, even in relation to targets: I don't accept - it's not that I don't accept, it's not a question of acceptance-better stated, I cannot conceive of the same targets for Lisbon as for the interior or the remote interior, which is practically uninhabited, deserted, etc. etc.

In this regard, the debate surrounding adult education policy, its political and conceptual dimensions, besides the issues which relate to its development, tends to be undertaken differently by the various heads interviewed, apparently according to the institutional context to which they belong. 


\section{Policy Appropriations: The Rules of Funding and the Actions in the Terrain}

In addition to service contracting, in terms of the quantitative targets related to determined items of achievement and the setting up of teams to correspond with the result levels, the interviewees claimed that the rules of funding were restrictive and limiting, and that the chosen definition of expense categories has implications of constraint for the activities developed. Once again, those responsible for the New Opportunities Centres embedded in the local development associations tend to highlight an interpretation and a contestation of funding, more focused on its political implications, indicating the pedagogical consequences, but also the consequences in terms of the scope of educational intervention. All eight heads interviewed unanimously state that funding restricts the scope of the activities developed. In this manner, as expected, the scope of the adult education policy, in the tension between mandate and capacity (Dale and Ozga 1991), is marked by the rules of funding. The coordinator (male) of the NOC Vila do Porto (public secondary school) explains,

For example, I have an Adult Education and Training Type $\mathrm{C}$ class of 25 students, which I cannot open right now. ... Because it eventually implies hiring staff and I cannot draw up contracts.... The school cannot do so. The Regional Direction has been given instructions that, from the 23rd of December [in 2010] onwards, staff cannot be hired for new courses.

Likewise, the coordinator (female) of the NOC Rosal (municipal town council) continues,

With regard to financing, I think that the great shortcoming in the Initiative is that, in this funding, we cannot include activities of a cultural nature which we could undertake with our trainees or with our adults ... This is true again when we talk about the target-public as well, because we know that we are addressing a specific audience and that is clearly defined: the group of over 18s who, therefore, do not have the minimum 12th year school qualification. And from the start, we immediately know that those who have already completed the 12th year, no matter how much we would like to continue accompanying them, are not included in the terms of this project.

Another coordinator (female) of the NOC Lages (private vocational school) asserts,

In some way, because the NOC only intervene in the RVCC and in adult guidance, don't they? Now, obviously we do ... the activities we do which are for the community or the activities that we want to do ... are supported by the team of trainers who do ... who work beyond their set hours. And who like to show and motivate the adults who are involved in the Process.

In the statements gathered, there is a clear criticism founded on this experience of an unequal relationship with the supervising entity when executing a policy, whose objectives, conditions and results seem to be imposed rather than negotiated. On the other hand, there is an equally clear adherence to, and positive assessment of, other dimensions of this policy by the interviewees, as well as an assertion of options, as those underlined in the next quotation, even when these are counter to those favoured by the supervising body and, further, a vivid involvement and appropriation of action in 
the terrain. The coordinator (male) of the NOC Vila do Porto (public secondary school) says,

I have, for example, a policy of "forcing" people to do, and that their options are about doing training, and I have percentages of orientation towards the RVCC that are the opposite of the national average: for the secondary RVCC, I have about 25 per cent and the national average is approximately 75 per cent; for different types of training, for adult education and training courses, around 70 to 80 per cent.

These experiences are particularly expressed in testimonies about local and/or community dynamics in the building of educational interventions; this is also the case of inter-institutional relationships, which are often described in terms of cooperation and competition, and the experimentation with forms of articulation that they called "networks." The director (male) of the NOC Vila da Vitória (local development association) observes,

We have a platform, we have an informal network where the Centres meet occasionally, and when I say the Centres ... on various levels, from the coordinators, the professional teams and each of these, obviously, according to sectors, also the RVCC professionals and trainers; therefore, they meet, and also do some training, or self-training, and there is a sound spirit moving ... [he mentions four municipalities near to their own] but this informal network allows for a dialogue here, nobody has turned his back on others and there is consequently ... an interconnection regarding intervention in the territory.

The coordinator (female) of the NOC Estrela Polar (local development association) says,

Therefore, competition is daily experienced. Fortunately, here in [the municipality] we have reached an agreement, to operate as a network. So, to operate as a network, we have allocated territories. Each one has a defined territory and, consequently, we have become not just competitors ... it is true that we all have targets to meet and we want to meet them, so that we are competitors. But at least there is none of that ferocious competition, it's just as well that we work and cooperate with each other, isn't it? We allocate time and places and in this way we are all covered in a coherent manner.

\section{Agency Dispersion for Private and Public Domains: A Lack of Confidence and/or a Cruel Mistake}

Some of the important vectors in the governance debate focus on the theme of the state's repositioning in relation to the market and the denominated third sector, as well as the redistribution of roles and tasks in those institutional domains. According to Ranson, here there's some tension in governance, which mirrors understandings about civil society and conceptions about which of its faces (e.g. community or market participation or interests) to strengthen (Ranson 2012, 30-4). Indeed, this constitutes one of the processes under way in the setting up of governance as a new matrix of 
social regulation. This is so, both in its hegemonic version with a neoliberal tone, as well as in its counter-hegemonic expression of social experimentation with a political meaning of constructing participatory processes in order to respond to aspirations of social recognition and redistribution. Thus, the state's role and that of the excluded, in the governance arrangements being analysed, provide clues for the exploration of this "political meaning" (Santos 2005). Furthermore, in the view of Clarke and Newman (1997), the dispersion of the state's power to the periphery was a political strategy to reconstruct both the state as well as the coordination of its welfare functions. These processes involve delegating the state's authority to subordinate entities who will act on its behalf, configuring the distribution of "agency" (Clarke and Newman 1997, 25, 29). On the other hand, in the present scenario of transformation, national, local and global spaces are recreated as processes and social relationships, and as dimensions of the education world.

\section{Whose Educational Agency: State and Schooling Domination, Citizenship or Business Participation?}

The voices of interviewees responsible for associations of local development expressed criticisms relating to the massive involvement of public institutions (schools and training centres) in the New Opportunities Centres network integrating the Recognition, Validation and Certification of Competences device in Adult Education and Training, which occurred between 2006-2009. They question the domination of state and schooling pervading educational practices and the whole sector; they claim participation and the construction of a regulated and supervised local and institutional policy, which is not imposed or confined by public authority. The director (male) of the NOC Vila da Vitória (local development association) says,

\footnotetext{
... at this point, we should follow the path towards the decentralisation of power, to place greater trust in civil society, and civil society has already proved that it can manage well and that it is capable of managing the same thing with far fewer financial resources, and that it can manage very well with fewer human resources, and that it is able to manage-with the same, if not greater, quality than that of the State-some of the initiatives that are important to the policies of the State itself.
}

On the other hand, in the same argument, the complexity and internal heterogeneity of the universes which have formally and legally been organised into public (in its peripheral, central, regional and local diversity) and private (in its profit-making, civic, social and cultural components) are omitted, as well as the many, potentially contradictory, interests they support. From the point of view of the head of the NOC of the local development association Vila da Vitória, the key reference point for interpretations about the governance arrangement of the RVCC device and of adult education and training courses focuses on the local action and development values. In this light, the involvement in policy implementation is experienced as a dissatisfactory 
relationship (which includes but is not necessarily dominated by tensions) on the part of those actors for whom dependence on the central state is an often inevitable and uncalled-for condition of the capacity to influence local life.

Contrary to this point of view, other testimonies from interviewees of public entities, such as the head of the NOC Fenix - a public training centre of participated management - describe the governance of the RVCC device, with contracting services involving private, and for-profit entities, as a "cruel" "mistake," when referring to the manner in which this was undertaken. He (the coordinator of the NOC Fenix, public centre of vocational training) explains,

since training entities present training plans which are very often in line with their conveniences, in accordance with the business model they have created and not interconnected with the regional interest, and that must be concerted, the regional interest with the entity's interest ...; what happened was that a path was opened for any type of institution to be a New Opportunities Centre ... Adult education and training cannot be dealt with as if it was a business matter; there is no business, it's a structural issue, it's an area that requires investment and cannot be seen as a business and, therefore, because it cannot be seen as a business, I find it cruel to hand it over to the private sector. ... The State has made use of the fact that there is a private sector in training, and gave them another opportunity for their businesses.

The claim expressed by this interviewee, although their concerns and meanings are different from those identified in the abovementioned opinion of the director of the NOC Vila da Vitória, also simplifies the state, market and third sector social relationships of institutional coordination which constitute the public and private domains. The argument advances in favour of "state control" (that is, the prevalence of formal and school modalities and standards) of the field of adult education and training. In this way, the opposition to the involvement by the "training business" component is grounded in the belief that this constitutes a deviation of resources and public assets by specific interests, enabled by the formula of governance adopted by this public policy. Nevertheless, this position ignores the adult education and training agents involved in cultural, civic and social activities and movements. In addition, the history of adult education in Portugal, and indeed worldwide-be it through positive or negative examples-asks for a more cautious and informed understanding: from a perspective of democratic participation and the assurance of rights and social justice, the construction of synergies and solid articulations between public and state structures and policies and the autonomous and self-organised action by citizens seem vital.

\section{The State's Great Strategy? Reaching People: "Localisation" and Community Involvement}

In turn, the New Opportunities Centre Coordinator of the local development association Estrela Polar sees the more instrumental aspect of this mediation of social policy 
assumed by subcontracted entities "when civil society is called above all to carry out tasks rather than to participate in decisions and social control" (Peroni 2012, 22).

The ambiguity and ambivalence of the processes that construct these institutional arrangements of governance are insinuated in the discourse, where an attempt surfaces to articulate the different types of logics in tension. In this case, the tendency for assistance and remedial action-which remit to the "local" the support provided to the fragile social bond, and the compensation for the many insufficiencies of economic and social policies - does not manage to extinguish the assertion of the dynamics of subsidiarity and a proper space of action, which are thus reduced to their minimal expression. The coordinator (woman) of the NOC Estrela Polar (local development association) asserts,

I believe there was the awareness that the public sector did not possess the openness, or the proximity required by populations to be able to mobilise them and meet the objectives of qualification and, therefore, this demand. This strategy was: ... "If I know I am unable to get there with my resources, I know there are entities in the field that are private and, consequently, much more flexible to begin with, and worried about proving that they can succeed" ... Because [the state] realised this was the only way to respond to the greatest possible number of people. On its own, due to its work practices and distance from populations, because of its lack of knowledge, and this leads to not knowing them [the population] so well, what their needs are and how to help them, and the associative sector ends up being ..., ends up having to respond to them and that's it. I think that was the State's great strategy.

Another opinion, expressed by the head of a NOC of a municipal body, values the diversity of the agents involved and considers that such a spectrum potentiates the population's mobilisation towards adult education and training and the richness of socio-educational practices. The coordinator (female) of the NOC Rosal (municipal town council) avers,

If this had been an initiative limited to schools, in my opinion, it would not have had the scope it has today, I believe we would not have reached so many people, we would not have had such a significant response nor such great community involvement ... So, I see this as being positive ... because, in fact, I think this project has gained through its diversity, because it involves such heterogeneous entities which are so rich in their diversity.

The contradictory and partial arguments (such as the visible bias of positions) reveal the diversity and divergence of interests and interpretations supported by the actors and agencies involved in the governance of the sector. Ball claims $(2010,155)$, as has been widely noticed in other sectors, the institutional formula adopted for the coordination of activities

blurs the already fuzzy divides between the public/state, the private and the third sectors and produces a new mix of hierarchies, markets and heterarchies. That is, it replaces or combines bureaucracy and administrative structures and relationships with a system of organisation replete with overlap, multiplicity, mixed ascendancy and/or divergent-but-coexistent patterns of relation. 


\section{GOVERNABILITY AND AGENCY DISTRIBUTION: EXPANSION AND CONTESTATION OF THE STATE'S POWER IN THE EDUCATIONAL TERRAIN}

The testimonies presented by the interviewees allow one to observe a varied institutional appropriation by the bodies involved in the policy in action in the field. On the one hand, as seen in the last section and related to the research issue of the interpretations about RVCC policy, there is the defence of an alternative legitimacy and competency vis-à-vis state agents' action; yet, we don't hear about actions founded on forms of social power, which are alternative and separated from the state, beyond the probable influence on certain processes and domains of local life. Is this silence pointing to the fragility of organised action by citizens, repeatedly observed in Portugal (see Hespanha et al. 2000; Santos 1993)?

In an argument of a different sense, the submission of common public welfare and general interest to the private logic of profit-making is mentioned, be it associated or not with the specific interests of training demanders, thus converted into consumers. The position defended suggests that the sector reveals signs of co-optation by the different forms of social power, whose sources are both the local world of commerce/corporations as well as individual demand. The process thus referred to evokes structural instability associated with the dispersion of the state's power through the coordinating forms of social welfare set in motion by the managerial state's reforms (Clarke and Newman 1997).

Other interpretations reveal both the expectation of policy consolidation through social mobilisation, enhanced by the involvement of a myriad of heterogeneous entities, and the "localisation" of social problems and control management, convening citizens' organisations to this end. Even when these are empowered by their involvement with the population's realities, they are still the subordinate arms of assistance, implementing the palliative and remedial political agendas; they do not decide but rather execute in favour of the state's legitimacy and the sustainability of the social order. In this way, the state moves away from the commitments and demands linked to the educational rights of the most abandoned sectors of the adult population. Most of these population segments continued to be disadvantaged as a result of the deficits of the recent Portuguese semiwelfare state (Santos 1990) and of the failures of the current economic, social and employment policies handed over to the creation of the neoliberal governance.

In this sense, in these testimonies of governance in action, we find expressions of the institutionalisation of the managerial reform of dispersion (retraction and expansion) of the state's power: one can observe that the latter has asserted itself as a strategic manager, it monopolises the centre of policy decision-making, convenes organisations in civil society and contracts policy execution, thus delegating segments of the its power, responsibilities and functions. So, policy development involves a myriad of heterogeneous actors and organisations, besides state institutions. However, the process is better described through the idea of the instrumental extension of the governance 
circle in order to carry out state policies, rather than "network (or 'polycentric') governance" (Junemann and Ball 2013, 424), given the prevalence of strict supervision and of the terms of service contracts by the central state. As Jessop suggests, one could consider sectors or moments to "includ[e] what we might term the articulation of government and governance"; since "the same modes of regulation and/or governance could be configured into rather different economic or political projects," the "calling for partnership ... could be followed by struggles to 'manipulate' partnership for economic or political purposes" (Jessop 1995, 20).

The interviewees further report disputes relating to the institutionalisation of this modality of educational service provision, which illustrates governance/regulation as a terrain of struggle and political action. As other studies have argued, and we have sought to point out, what is called "new localism" is still within the domain of the new public sector management, even if "there remains a residual potential to develop more democratic forms of engagement" (Avis 2009, 634). Furthermore, and now with reference to the EU, Nóvoa indicates that change discourses and practices "do not direct our attention to a deepening of democratic decisions, but instead to a reinforcement of 'new means' (governance, benchmarking, good practices etc.) and 'new powers' (networks, informal groups, mass media etc.)" encompassing "a strategy to shift the discussion away from matters of government (inhabited by citizens, elections, representation etc.) and place it in the more diffused level of governance (inhabited by networks, peer review, agreements etc.)" (Nóvoa 2010, 270).

Thus, as discussed in the section on the state as a strategic manager, the testimonies show: (1) an interpretation of RVCC policy that contests the democratic nature of the policy, in terms of participation and autonomy and the recognition of communities' and local bodies' own voices and spaces of intervention; (2) the persistent challenge of some orientations and practices against limitations imposed on the scope of educational action and the attempts of enrichment of pedagogical action and of the learning contexts and processes; (3) the dynamics of the construction of local inter-institutional relationships of cooperation (and concurrence). Alongside these, there are further issues: the concern about producing outcomes and conquering space and "customers" in the "market" of adult education and training; the adherence to restricted and instrumental views of the sector, or its colonisation by perspectives and languages, now hegemonic and imported from economics and management; and even, and not infrequently, an authoritarian and disqualifying view towards the populations and recipients of public action.

\section{FINAL CONSIDERATIONS}

An analysis of the perspectives, orientations and practices supported by heads of institutions suggests the contours of delimitation and capacitation of action, put into place by the terms of a particular educational (managerial) state's policy. The discussion of governance in action allowed by the heads' testimonies reveals appropriations of an adult education and training public policy whose political meaning strongly relates to 
the concerns of governability. The controversy about whose agency (state, schooling, citizens, business) defines this public policy relates to the educational change it promotes; this change integrates elements of privatisation, commercialisation and liberalisation of education, articulated with processes of state control and the instrumental enlargement of the governance circle. Thus, the incorporation of civil society's action in policy development-and in this way the delegation of the state's power-in accordance with the terms and objectives defined by the government, is accompanied by the expansion of its control and legitimation capacity ("the state's great strategy"). In this framework, the attempts and practices aimed at promoting strong roots in the community and amplifying the scope of social, educational and pedagogical intervention seem severely conditioned, as some interviewees underline, questioning local recognition and participation in policy development. Consequently, it remains very difficult to build links between socio-political innovation (in this case the RVCC device, as an adult education policy developed in the NOC centres) and social redistribution, recognition and emancipation. Nevertheless, even if they are interstitial, political and pedagogical contestation and struggle have taken on expression and shape in discourses and practices which are as persistent as they are fragile and contradictory.

\section{REFERENCES}

Afonso, A. J. 1998. Políticas Educativas e Avaliação Educacional. Para uma Análise Sociológica da Reforma Educativa em Portugal (1985-1995). Braga: Universidade do Minho.

Antunes, F. 2011. "Governação, Reformas do Estado e Políticas de Educação de Adultos em Portugal: Pressões Globais e Especificidades Nacionais, Tensões e Ambivalências." Revista Crítica de Ciências Sociais, no. 92, 3-29. https://doi.org/10.4000/rccs.3861

Antunes, F., and P. Guimarães. 2014. "Lifelong Education and Learning, Societal Project and Competitive Advantage: Tensions and Ambivalences in Policy and Planning of Educational Change in Portugal." Globalisation, Societies and Education 12 (1): 71-91. https://doi.org/10.1080/14767724.2013.858985

Avis, J. 2009. "Further Education in England: The New Localism, Systems Theory and Governance." Journal of Education Policy 24 (5): 633-48. https://doi.org/10.1080/02680930903125137

Ball, S. J. 2009. "Entrevista com Stephen J. Ball: um Diálogo sobre Justiça Social, Pesquisa e Política Educacional (entrevista de Jefferson Mainardes \& Maria Inês Marcondes)." Educação e Sociedade 30 (106): 303-18. https://doi.org/10.1590/S0101-73302009000100015

Ball, S. J. 2010. "New Voices, New Knowledges and the New Politics of Education Research: The Gathering of a Perfect Storm?" European Educational Research Journal 9 (2): 124-37.

https://doi.org/10.2304/eerj.2010.9.2.124

Ball, S. J., and C. Shilling. 1994. "Guest Editorial: At the Cross-Roads: Education Policy Studies." British Journal of Educational Studies 42 (1): 1-5. https://doi.org/10.1080/00071005.1994.9973979 
Barros, R. 2012. As Políticas Educativas para o Sector da Educação de Adultos em Portugal. Lisbon: Chiado Editora.

Bowe, R., S. J. Ball, and A. Gold. 1992. "The Policy Process and the Process of Policy." In Reforming Education and Changing Schools. Case Studies in Policy Sociology, edited by R. Bowe, S. J. Ball, 6-23. London: Routledge.

Clarke, J., and J. Newman. 1997. The Managerial State: Power, Politics and Ideology in the Remaking of Social Welfare. London: Sage.

Dale, R., and J. Ozga. (1986) 1991. Introducing Education Policy: Principles and Perspectives. E333 Policy Making in Education: A Third Level Course. Milton Keynes: The Open University.

Dale, R. 1989. The State and Education Policy. Milton Keynes: The Open University Press.

Dale, R. 1997. "The State and the Governance of Education: An Analysis of the Restructuring of the StateEducation Relationship." In Education:Culture, Economy and Society, edited by A. H. Halsey, H. Lauder, P. Brown and A. S. Wells, 273-82. New York: Oxford University Press.

Dale, R. 2001. "Globalização e Educação: Demonstrando a Existência de uma 'Cultura Educacional Mundial Comum' ou Localizando uma 'Agenda Globalmente Estruturada para a Educação?' Educação, Sociedade e Culturas, no. 16, 133-69.

Dale, R. 2009. Introduction to Globalisation and Europeanisation in Education, edited by R. Dale and S. Robertson, 7-19. Oxford: Symposium Books.

Hespanha, P., A. Monteiro, A. C. Ferreira, F. Rodrigues, N. H. Nunes, M. J. Hespanha, R. Madeira, R. Hoven, R. Van den Hoven, and S. Portugal. 2000. Entre o Estado e o Mercado. As Fragilidades das Instituições de Protecção Social em Portugal. Coimbra: Quarteto.

Hespanha, P., S. Ferreira, and V. Pacheco. 2014. "O Estado Social, Crise e Reformas." In A Economia Política do Retrocesso. Crise, Causas e Objectivos, edited by J. Reis, 189-281. Coimbra: Almedina.

Jessop, B. 1995. "The Regulation Approach, Governance and Post-Fordism: Alternative Perspectives on Economic and Political Change?" Economy and Society 24 (3): 307-33. https://doi.org/10.1080/03085149500000013

Junemann, C., and S. J. Ball. 2013. "ARK and the Revolution of State Education in England." Education Inquiry 4 (3): 423-41. https://doi.org/10.3402/edui.v4i3.22611

Lima, L. C., and P. Guimarães. 2011. European Strategies in Lifelong Learning. A Critical Introduction. Opladen: Barbara Budrich Publishers.

Melo, A. 2007. "Educação e Formação de Adultos em Portugal como um Projecto de Sociedade." In Políticas de Educação/formação: Estratégias e Práticas, edited by Conselho Nacional de Educação, 65-71. Lisbon: CNE.

Melo, A., L. C. Lima, and M. Almeida. 2002. Novas Políticas de Educação e Formação de Adultos. Lisbon: ANEFA. 
Newman, J., and J. Clarke. 2012. “Gerencialismo.” Educação e Realidade 37 (2): 353-81. https://doi.org/10.1590/S2175-62362012000200003

Nóvoa, A. 2010. "Governing Without Governing." In The Routledge International Handbook of the Sociology of Education, edited by M. W. Apple, S. J. Ball and L. A. Gandin, 264-73. New York: Routledge.

Peroni, V. 2012. "A Gestão Democrática da Educação em Tempos de Parceria entre o Público e o Privado." Pro-Posições 23 (2): 19-31. https://doi.org/10.1590/S0103-73072012000200003

Ranson, S. 2012. "Schools and Civil Society: Corporate or Community Governance." Critical Studies in Education 53 (1): 29-45. https://doi.org/10.1080/17508487.2012.635670

Santos, B. de S. 1990. O Estado e a Sociedade em Portugal (1974-1988). Oporto: Afrontamento.

Santos, B. de S. 1993. Portugal: Um Retrato Singular. Oporto: Afrontamento.

Santos, B. de S. 1997. "Por uma Concepção Multicultural de Direitos Humanos." Revista Crítica de Ciências Sociais, no. 48, 11-32.

Santos, B. de S. 2005. "A Crítica da Governação Neoliberal: o Fórum Social Mundial como Política e Legalidade Cosmopolita Subalterna.” Revista Crítica de Ciências Sociais, no. 72, 7-44. https://doi.org/10.4000/rccs.979

Seddon, T., S. Billet, and A. Clemans. 2005. "Navigating Social Partnerships: Central Agencies-Local Networks." British Journal of Sociology of Education 26 (5): 567-84.

https://doi.org/10.1080/01425690500293488 